\title{
THE SUICIDES OF OTHO AND NERO IN SUETONIUS
}

\author{
M B Charles (Southern Cross Business School, Southern Cross University) \\ and E Anagnostou-Laoutides (School of Philosophical, Historical and \\ International Studies, Monash University)
}

\begin{abstract}
Both Otho and Nero are usually regarded as 'bad' emperors in the historical record, and their conduct is often assimilated. Yet Suetonius' treatment of their suicides, while cleverly approximating the two events, nevertheless shows clear differences. While Nero appears weak and without resolve, Otho bravely shrugs off his supposed effeminacy and dies a true Roman emperor, more so since his death was intended to preserve the lives of his fellow citizens. Suetonius deliberately composed Otho's exitus scene in such a way as to leave the reader with a positive impression of the emperor, simultaneously to the detriment of Nero.
\end{abstract}

It is well known that Suetonius placed a good deal of import on the deaths of his imperial subjects, including the omens presaging them, and the precise context in which the emperors met their ends. ${ }^{1}$ These death-scenes, it follows, are meant to provide a final illumination of the character of his subjects, something very much in keeping with general attitudes in the ancient world towards death. ${ }^{2}$ Describing a person's manner of death, to Suetonius and his contemporaries, effectively constituted providing a person's literary epitaph, distilling much of what we need to remember about that person's character, with Arand (2002:230-232) even suggesting that the deaths of 'bad' emperors offer more scope for literary effect. Given Suetonius' general propensity to arrange his material so as to cohere with

Translations in this article are taken directly or else are adapted from the relevant Loeb editions. Abbreviations follow the 'Liste des périodiques' in L'Année philologique. All dates are AD. We would like to thank one of Akroterion's referees for providing useful suggestions on how to improve the article.

2 On the importance of death (and life) as a means to determine 'the condition of human life' (humanae ... vitae condicionem), see Val. Max. 9.12 praef. On this, see Wardle 2007:444, with Edwards 2007:6-10, 144-160, where she explains the performative aspects of death for elite Romans, especially those embracing Stoic or Stoicizing ideals, and who wished to highlight, in their manner of death, a sense of constancy of character; cf. Hill 2004:184, on suicide in the Empire representing a means of establishing 'one's status as a moral witness in the community'; with Erasmo 2008:10-11, 15-20, 33-41, 50$55,61-74$, on the performative elements of death rituals. See also Bardon 1956:207-209, on the literary genre of the deaths of famous men, which, in the Roman world, often concentrated on the 'martyrdoms' of the Stoic opposition - something which, as Wallace-Hadrill 1995:11, n. 18 points out, is 'missing' in Suetonius' work. In fact, as will be seen, Otho's death is arguably the closest that we come to a Stoic martyrdom. 
his general estimation of his subject's character, it is also highly likely that these death-scenes were manipulated by the biographer so as to highlight the virtues or vices supposedly inherent in the imperial characters of which he treats. The deathscenes of Otho and Nero, given that they both deal with suicide, therefore provide a useful lens through which to look at these arguably programmatic literary distortions. ${ }^{3}$

Aside from their suicides, there are other similarities between Nero, the last of the Julio-Claudians, and Otho, who had toppled his predecessor Galba in a bloody coup d'état. For example, they are both described, inter alia, as once having been close companions (Suet. Oth. 2.2; Tac. Hist. 1.13.3), and having even shared the same woman, Poppaea Sabina, allegedly wife of both men at some point (Suet. Oth. 3.1-2; Tac. Ann. 13.45.4). ${ }^{4}$ Furthermore, Otho's accession prompted some to fear that he would be an alter Nero, ${ }^{5}$ such was the alleged similarity of the two emperors' characters, including an addiction to ostentatious luxury, sexual depravity, and general licentiousness. ${ }^{6}$ In effect, their characters are largely assimilated in the ancient literature. As a result, it should prove instructive to juxtapose these two accounts, which differ considerably with regard to the circumstances leading to the suicides described. ${ }^{7}$

3 Van Hooff 2004:108-109 discusses the deaths of Otho and Nero (along with that of the much later ruler Magnentius) as an attempt to save their reputations, yet Nero's hesitation, as will be seen, casts his cowardly nature in relief.

4 This largely coheres with Plut. Galb. 19.2-5 — a real marriage it seems between Otho and Poppaea; but cf. Tac. Hist. 1.13.3 and Cass. Dio 61.11.2, where the marital status is not clear. At this locus, Nero 'gave' Poppaea to Otho, and they both enjoyed her affections.

5 Cf. Tac. Hist. 1.13.4: Neronis ut similem. Otho allegedly attempted early in his reign to pose as a kind of 'Nero-Otho' by restoring the statues of Poppaea and encouraging the exhibition of Nero's portraits; see Tac. Hist. 1.78.2; Plut. Oth. 3.1, with Suet. Oth. 7.1 (on not declining the cognomen 'Nero' given to him by the crowds). He also supposedly intended to marry Nero's widow (Suet. Oth. 10.2) and he brought back to prominence Nero's eunuch Sporus (Cass. Dio 64.8.3), with the suggestion of intimacy between Otho

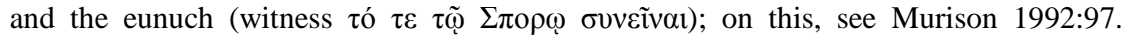
Akroterion's anonymous referee also points out that Otho's hairstyle, in statues of the emperor, also has a decidedly Neronian appearance.

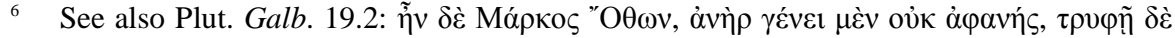

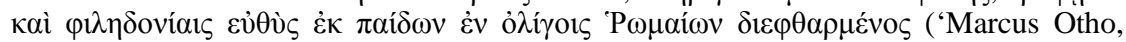
now, was a man of good lineage, but from his very childhood corrupted by luxury and the pursuit of pleasure as few Romans were'). The approximation of the two supposed tyrants had already been undertaken by Pliny the Elder ( $H N$ 13.22), who recognized in Nero and Otho the symptoms of unmanly luxuria; see also Tac. Hist. 1.22.1.

As Mouchová 1968:57 points out, 'Es liegt auch auf der Hand, dass bei der literarischen Bearbeitung dieser Persönlichkeiten, die sich entschlossen, ihr Leben durch Selbstmord zu beenden, einige gleiche Momente und Motive auftauchten'. 
We begin with Nero. The material concerning his death is the longest for any emperor presented by Suetonius, which suggests, once again, that this exitus scene is of especial importance. As Lounsbury (1987:3) rightly suggests, it is 'perhaps the most vivid and memorable passage of narrative in all of the De Vita Caesarum'. ${ }^{8}$ At Ner. 46, Suetonius presents a long list of the dreams, auspices and omens that presaged Nero's death. In particular, he was plagued with dreams of those whom he had killed, including his mother Agrippina the Younger, and his former wife Octavia (Ner. 46.1). ${ }^{9}$ When a speech of Nero against the rebel Vindex was being read in the senate (Ner. 46.3), immediately after the words 'the wretches will suffer punishment and will shortly meet the end which they deserve' (daturos poenas sceleratos ac brevi dignum exitum facturos), all responded with the ambiguous 'you will do it, Augustus' (tu facies, Auguste). ${ }^{10}$ The tone of Nero's death, then, is retribution for his many crimes. ${ }^{11}$

When word came that other armies had revolted, he grabbed some poison, fled to the Servilian gardens, but only after having sent his most trusted freedmen to Ostia to get a fleet ready (Ner. 47.1). At the Servilian gardens, he tried to persuade some tribunes and centurions of the Guard to accompany him. But these

8 See also Bradley 1978:273. Sansone 1993:179-189 argues that the narrative of Nero's last hours, written by an unknown hand but exploited by writers such as Suetonius, was based on the myth of Er, found at the end of Plato's Republic.

9 Cf. Cass. Dio 63.28.4-5.

10 Rolfe 1997:164, n. 'b': 'Of course used in a double sense'.

11 Dio (63.26.5), whose account of Nero's exploits has many similarities with that of Suetonius (see Griffin 2000:236-237; Shotter 2005:107), listed the automatic opening of the doors of Augustus' mausoleum and Nero's bedroom during one and the same night among the omens foretelling the emperor's death. Given that Nero, with his cruelty and extravagance, exemplified the very opposite to the model of clemency (clementia) and self-control (continentia) promoted by Augustus, it is fitting that Nero's failure to be pater patriae would be signified in connection with Augustus. Luxuria and crudelitas were famously attributed to Nero by Suetonius in Ner. 26.1, where they appear alongside petulantia, libido, and avaritia (insolence, lust, and greed), all aspects of his intrinsic wickedness and by no means merely signs of his uneasy adolescence; note, too, luxuria immoderatissima at Suet. Ner. 51, with Tac. Ann. 13.25.1-3; 14.14-15 (on his criminal or unbecoming actions). See also Pliny's condemnations of Neronian luxuria: e.g., use of tortoiseshell at $H N$ 16.233; incense (at Poppaea's funeral) at 12.83; pearls at 37.17; tableware at 37.19-20; for perfume and luxuria, see 13.22. On Nero failing to emulate Augustus, see Champlin 2003:144; cf. Seneca's De Clementia, especially 1.911 , where Nero is urged to practice clemency in his youth so as to surpass Augustus, who was renowned for clemency in his old age; and Suet. Aug. 73.1, on Augustus' simple tastes. 
either gave an evasive answer or openly refused, with one asking 'Is it so dreadful a thing then to die?' (usque adeone mori miserum est? Ner. 47.2) - a line from Vergil's Aeneid (12.646). Nero then determined whether he should go 'as a suppliant' (supplex) to the Parthians, Rome's traditional enemies, or to Galba, who had revolted against Nero; or whether he should mount the rostra, dressed in black, and beg the people's forgiveness so that they would allow him the prefecture of Egypt (Ner. 47.2). A speech to this effect was reportedly found afterwards, but, fearing the angry reaction of the mob, he failed to deliver it (Ner. 47.2).

At midnight, Nero found that all had deserted him, save for a few followers (Ner. 47.3). He then sought someone to kill him, either the gladiator Spiculus, or any percussor, so that he could meet a relatively painless death, ${ }^{12}$ but to no avail: 'Have I then neither friend nor foe?' (ergo ego ... nec amicum habeo nec inimicum: Ner. 47.3). ${ }^{13}$ Nero then sought a secure place to ponder his fate. His freedman Phaon offered his suburban villa, and he took off in that direction, wearing an old cloak, covering his head, and holding a handkerchief before his face (Ner. 48.1). After avoiding attention, save for the recognition of a retired Guardsman (Ner. 48.2), he made his way - with extreme difficulty unbecoming his station - to the villa. Here, Phaon urged him to hide in a pit, but Nero refused to go underground while still alive (Ner. 48.3). Though suffering from hunger and thirst, he refused any nourishment save for some lukewarm water (Ner. 48.4: aqua ... tepida). ${ }^{14}$ As he came to realize his position, and despite the fact that his companions 'one and all urged him to save himself as soon as possible from the indignities that threatened him' (uno quoque hinc inde instante ut quam primum se impendentibus contumeliis eriperet), Nero asked them to dig a grave before him, and bring some water and oil (Ner. 49.1). ${ }^{15}$ As this was being done, he wept and said repeatedly 'What an artist the world is losing!' (qualis artifex pereo: (Ner. 49.1). ${ }^{16}$

12 According to Rolfe (1997:168, n. 'b'), the word 'implies experience in dealing death. Nero wished to be killed swiftly and painlessly'.

13 Cf. Cass. Dio 63.29.2.

14 Dio (63.28.5) also refers to the water that Nero tasted during his last hours. Note his ironic comment: 'So this is my famous cold drink' ( $\tau$ ò $\alpha ́ \pi \varepsilon \varphi \theta o v)$. Dio (63.28.5) states that this was water of a sort that Nero had never tried before, thus reflecting Suet. Ner. 48.3, where Nero exclaims 'haec est ... Neronis decocta' - yet it was just some water scooped out of a pond.

15 I.e., to wash his corpse before burning it.

16 On the meaning, see Champlin 2003:49-51, who translates artifex as 'craftsman', and so 'what an artisan I am in my dying', not an artist, so low had he fallen. This view, which seems far too literal, is supported by Shotter 2008:153; cf. Bradley 1978:277 ('artist'), and see also Connors 1994:230. Yet Syme (1971:109, following on from id. 1958:41) observes that 'It is not the artist or the aesthete that the world is losing, but the great showman', which ties neatly into what we know of Nero's desire to treat his people to 
Still, Nero hesitated to die, until a courier brought news that he had been declared a public enemy, and that he would be executed 'in the ancient fashion' ( $u t$ puniatur more maiorem: Ner. 49.2). ${ }^{17}$ Seizing two daggers, he tested the point of each, and put them away, saying that the hour had not yet come. He pleaded with Sporus, his eunuch 'wife', ${ }^{18}$ to wail, and begged someone to set an example by taking his own life, all before reproaching himself 'for his cowardice' (segnitiem suam: Ner. 49.3). Only as the horsemen arrived to arrest him did he plunge a dagger into his throat, aided by Epaphroditus, his secretary or a libellis (Ner. 49.3). His last words, to a centurion feigning aid, were 'too late' (sero) and 'this is fidelity' (haec est fides: Ner. 49.4). According to Suetonius, 'with these words he was gone, with eyes so set and starting from their sockets that all who saw him shuddered with horror' (atque in ea voce defecit, exstantibus rigentibusque oculis usque ad horrorem formidinemque visentium: Ner. 49.4). There is no serenity of

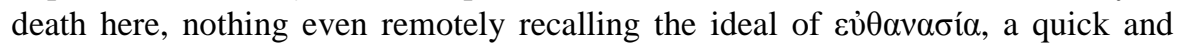
(relatively) painless death. ${ }^{19}$

We now turn to Otho. The account of Otho's death, described by Baldwin (1983:542) as 'a studied contrast with the pusillanimous suicide of Nero', is certainly shorter than that of the last Julio-Claudian, but this is to be expected in the shorter Vitae dealing with those emperors after Nero. After a few initial minor successes and then more significant setbacks in the war against Vitellius, and the battle of Betriacum in particular, 'Otho at once resolved to take his own life, rather from a feeling of shame, as many have thought with reason, and an unwillingness to persist in a struggle for imperial power at the expense of such danger to life and property, than from any success or distrust of his troops' (ac statim moriendi

countless spectacles. Ipok 1995:63-64 adds that, 'At best, the artifex is, in Suetonius, usually a shady character or professional actor. But even a legitimate thespian is not a respectable person'. Whatever the precise meaning of artifex here, that Nero supposedly fancied himself an actor and creator of spectacles further illustrates his tendency to stage his every action, and, of course, his death; on this, see Bartsch 1994:25-28. On Nero's alleged performances, see Erasmo 2004:117-121, with Cass. Dio 63.22.4-6 (a purported speech of Vindex vilifying Nero's theatrical propensities).

17 I.e., he would be stripped naked and beaten to death with rods, his head having been placed in a wooden fork (Ner. 49.2).

18 He had once been castrated at Nero's orders (Cass. Dio 62.28.2; Suet. Ner. 28.1). On the relationship of Nero and Sporus, see Champlin 2003:145-150; but cf. Woods 2009b:7382, with criticism of this study by Charles, forthcoming. That Sporus was implored to wail suggests that Suetonius is attempting, here, something of a parody regarding the actions of a 'good wife'. We thank Akroterion's anonymous referee for this suggestion.

19 Cf. Suet. Aug. 99.1-2. Suetonius' account of Nero's suicide clearly lacks the element of calm rationality about one's voluntary exit from life. It stresses suicide as the only option available, and thereby ridicules Nero's attempt to emulate the examples of men such as Seneca and Petronius. 
impetum cepit, ut multi nec frustra opinantur, magis pudore, ne tanto rerum hominumque periculo dominationem sibi asserere perseveraret, quam desperatione ulla aut diffidentia copiarum: Otho. 9.3). ${ }^{20}$ Indeed, we are told that he had fresh forces, and that others were on their way from Dalmatia, Pannonia and Moesia, while the already defeated troops were in good spirits, and were seeking to avenge their previous loss at Betriacum (Oth. 9.3) ${ }^{21}$ Suetonius tells us a story told to him by his father: when a soldier brought the news of the defeat at Betriacum to Otho's camp, the soldiers accused him of bearing false news, or else cowardice, upon which he fell on his sword (Oth. 10.1). ${ }^{22}$ Otho then resolved to ensure that no more brave men would die. ${ }^{23}$

Having made up his mind to commit suicide, Otho advised his brother, nephew and friends to see to their own safety, and dismissed them (Oth. 10.2). He then withdrew and wrote two brief letters, one to his sister, and another to Nero's widow Messalina; after this, he burned all his letters, lest they incriminate anyone, and distributed whatever funds were at hand to his domestic staff (Oth. 10.2). ${ }^{24}$ After discovering that those leaving the camp were being accused of desertion, he said 'Let us add this one more night to our life' (adiciamus ... vitae et hanc noctem), presumably to bring a sense of calm, and left his door open until a late hour so that anyone could speak to him (Oth. 11.1). He then drank some cold water and seized two daggers. After testing each dagger's point, he put one under his pillow, before sleeping 'very soundly' (artissimo somno quievit: Oth. 11.2). According to Suetonius, '[W]hen he at last woke up at about daylight, he stabbed himself with a single stroke under the left breast' (et circa lucem demum

20 On the rather complex Roman concept of pudor, see especially Kaster 2005:28-65; Thomas 2006:355-368.

21 See also Cass. Dio. 64.12.1. On reinforcements, see Tac. Hist. 2.32.2; 2.46 .3 (reference to Moesia and Aquileia); Plut. Oth. 15.4-5 (in the speech given by Otho on his decision to die). Shotter 1993:154 thinks that the 'utter despair' shown by the soldiers at Otho's death demonstrates that the Othonian cause was far from lost at the time of his suicide.

22 Repeated at Cass. Dio 64.11.1-2, although this story is ignored by Tacitus (Hist. 2.46.1$3)$.

23 In a speech that Dio (64.13.1-3) puts into Otho's mouth, he says that he would rather be a Mucius, a Decius, a Curtius, or a Regulus rather than a Marius, Cinna or Sulla, and asked to be allowed the privilege of following the example of the former group, since the example of the latter was hateful to him; cf. the somewhat more sober speech at Tac. Hist. 2.47.1-3.

24 Repeated at Cass. Dio 64.15.1 (burning letters and distributing money, though not specifically to servants), and Tac. Hist. 2.48.1. On distributing money, see also Plut. Oth. 17.1, though Plutarch claims that Otho did not distribute the money evenly, but according to merit, and with moderation. 
expergefactus uno se traicet ictu infra laevam papillam: Oth. 11.2). ${ }^{25}$ Otho expired soon afterwards and was hastily buried, as was his wish (Oth. 11.2).

Suetonius, like others who dealt with Otho's death, as discussed below, expresses some astonishment at the manner of decease, particularly on account of the 'great courage' (tantus animus) shown — something utterly at odds with the man's reportedly effeminate person and customs (Oth. 12.1). ${ }^{26}$ In Suetonius' own words: 'I am inclined to think that it was because of these habits that a death so little in harmony with his life excited the greater marvel' (per quae factum putem, ut mors eius minime congruens vitae maiore miraculo fuerit: Otho. 12.2). We are left to wonder whether Otho revealed his true self when faced with his greatest test, and whether Suetonius describes Otho's death in the way that he does so as to leave us with this positive thought. This is difficult to prove. Yet, by comparing the death vignettes of Nero and Otho, we gain a greater insight into what Suetonius was intending us to believe. This is especially the case given that the act of suicide was meant to be seen as a form of control. As a nod to Suetonius himself, it is best to do this per species.

\section{Common themes}

From the above, it is clear that some common themes emerge. These are worth discussing separately.

Courage and resolve:

Nero hesitates several times about killing himself, and even asks others (unsuccessfully) to perform the deed, so as to ensure the most painless death possible. It is only when faced with the immediate threat of capture by those who would execute him in a particularly violent manner that he ends his life. By way of contrast, Otho makes a clear decision to die, by his own hand, does not waver in his resolve, and does so on his own terms at a time determined by him alone - it is not his enemies who force him to die. Moreover, he did not want his followers to kill themselves to set an example, as did the coward Nero. It was precisely to avoid such an action that he resolved to commit suicide, having witnessed a Praetorian

25 Lopes Brandão 2010:38 thinks that these details, recorded by no one else, are 'exemplos do sentido do concreto e do gusto do biógrafo pelo horror e pelos pormenores mórbidos'.

26 He was said to have been completely depilated, wore a wig to conceal his scanty locks, was accustomed to smear his face with moist bread to prevent the growth of his beard, and sometimes wore the linen garment of worshipers of Isis (Suet. Oth. 12.1). 
guardsman ending his own life to avoid the ignominy of being called a coward. Each minute that Nero lived after his final tempestuous night merely serves to heighten his disgrace, whereas Otho dispatches himself at first light on his final day.

Accepting fate:

Before recognizing that he must die, Nero aims to escape. Without shame, he even considers surrendering to his enemies (the Parthians, or even Galba), with the use of supplex (Ner. 47.2) being particularly incongruous in the context of a Roman imperator. He even wonders whether, if he confessed his crimes, he would be allowed to rule Egypt, and so continue to live a life filled with decadent luxury a desire typical of Nero the fantasist. Fear of being torn apart by the bloodthirsty mob eventually put pay to this self-indulgent idea. But Otho seems to accept and even embrace his fate, despite the possibility of escaping, or even triumphing over his enemies - as Suetonius contends was still possible. Nero was in an absolutely desperate state, but Suetonius takes pains to suggest that Otho was not. Rather than run the risk of ignominious defeat on the field of battle, or even heavy Roman losses with victory, he accepts the role that Fate seemed to have allotted for him, and dies by his own unwavering hand as a consequence. ${ }^{27}$

\section{Concern for others:}

Aside from Otho dying because he wanted to spare further bloodshed, he also showed great concern about the immediate fate of his friends and family. ${ }^{28}$ Burning his correspondence so as to avoid incriminating others speaks to his concern for those left behind. One of his final acts was to distribute money among his lowly domestic staff, presumably to compensate for casting them into an uncertain future. That he took the time to write two letters also adds to the general picture of equanimity ${ }^{29}$ even as death approached. But Nero committed suicide for entirely personal reasons - a fear of torture and death - and was supposedly so selfabsorbed that he lamented the necessity of having to deprive the world of his wondrous artistry and showmanship. At one point, he even requests one of his

27 For discussion on resignation to fate, and its Stoic nuances, see Wardle 2007:451-452.

28 Wardle 2007:447, though dealing with Augustus, points out that demonstrating concern for family and friends is an important part of the exitus of the good emperor.

29 Tacitus Hist. 2.48.1 also refers to Otho's calm face, and that his words showed no fear (placidus ore, intrepidus verbis). Cf. Mallisard 1990:219, who contends that Tacitus' description of Otho's suicide is rather at odds with his usual emphasis on the calm, domestic settings in which Roman noblemen often chose to end their lives. 
followers to kill himself first so that he would gain enough courage to follow suit, a selfish action representing the antithesis of Otho's concern for his retinue's safety.

Exact manner of death:

What really ties the two death-scenes together is that both subjects seize two daggers, as several scholars have noticed in passing, and test the points of each. ${ }^{30}$ The similarities are surely not just the product of chance. ${ }^{31}$ While the cowardly Nero puts them both away, saying that the hour of death had not yet been reached, Otho selects one and places it under his pillow, before turning in for the night which he knew would be his last. Otho seizes the dagger at first light and plunges it into his heart, as seemingly indicated by the reference to his left breast (infra laeuam papillam: Oth. 11.2). Nero, after much hesitation, eventually stabs himself in the throat. Unlike Otho, who dies quickly, Nero lingers on a little to utter some final words, still clinging to life as long as he can. Though both emperors were cast as rather effeminate figures, it is Otho who dies in the manly way, having calmly resolved to commit suicide to benefit his people, while Nero was forced to choose suicide over the death of a base criminal.

\section{Drinking water:}

Both accounts refer to their subjects drinking water before death. ${ }^{32}$ Again, this surely cannot be coincidence. The reference to Nero drinking tepid water creates a striking contrast to the great luxury in which he had typically lived, thereby emphasizing his abject humiliation and fall from grace. Nero had systematically tried to turn the city into a place of crime, as Suetonius often reminds us (e.g., at Ner. 19.3, 27.1, 35.4), but his criminal onslaught had failed, and a punishment reserved for treacherous criminals awaited him (Ner. 49.2). It is no surprise, then, that he does not drink the kind of luxurious water (aqua decocta) invented by Nero himself, and which Pliny the Elder $\left(N H\right.$ 31.40) records in greater detail. ${ }^{33}$ Yet the

30 See Lopes Brandão 2010:38; Mooney 1930:301; Shotter 1993:157; Venini 1977:98. But they do not comment on the reasons for this. On similarities between the two accounts, see also Mouchová 1968:56-57, who at least provides some extended commentary on the similarities.

31 O'Gorman 2000:161 notes Dio's influence on Suetonius' description of Nero's suicide in terms of an 'unsatisfactory epilogue'. He further conjectures that Tacitus would have portrayed the death of Nero in as dark a tone as that used by Suetonius.

32 Venini 1977:98 makes no mention of this.

33 On the locus, see Woods 2009a:40-48, who suggests that Nero's cold drink was more than merely 'a sign of Nero's cupido luxus, despite what a hostile tradition claims' (46). 
reference to Otho imbibing cold water was clearly designed to contrast with Nero's pathetic circumstances, and may even hint at a more legitimate status for Otho, who died maintaining his dignity, as an emperor should, and with imperial amenities still at hand. ${ }^{34}$

\section{Dying a commander of troops:}

Although the very manner of Otho's death contrasts favorably with that of Nero, it is significant that the former dies in a military tent surrounded by his Praetorian Guardsmen, while the latter perishes hiding from the very same troops. By Suetonius' day, and indeed long before, it was abundantly clear that the emperor's position relied heavily on the support of Rome's military. The lurid and almost phantasmagorical narrative of Nero fleeing from his own soldiers reinforces the perception of Nero's fall, far from his military family, their protection and loyalty. He does not die an imperator. He dies an outcast. By way of contrast, Otho falls in the very bosom of his soldiery, and his guard's devotion to him is highlighted by Suetonius in his statement that 'many' of the soldiers present (multi praesentium militum) slew themselves not far from Otho's funeral pyre, after having kissed the hands and feet of the dead princeps (Oth. 12.2). ${ }^{35}$ There is little question that Otho dies a fully invested imperator, and no longer merely a base usurper.

\section{Concluding remarks}

Given the quite different treatment of the two deaths, it remains for us to determine why Suetonius presents what he does. The case of Nero poses few difficulties: we are surely meant to view his end as a manifestation of the disgraceful conduct that marked his life. His suicide, a punishment for his years of alleged criminality, effectively showcases his effeminacy and cowardice to the reader, and provides a final indication of his general unfitness to rule. As Wardle (2007:459) succinctly

Nero had apparently devised a new way of serving water. This required water that had first been boiled, and then cooled, to be placed in a glass vessel, and then plunged into snow. Ipok 1995:63, n. 25 wonders if the word is meant to be akin to decoctor, which can be "translated as "spendthrift" or "ruin", making decocta a ruinous drink'.

34 See also Lopes Brandão 2010:28, who also reflects on the point that both emperors drank some water before their deaths.

35 Cf. Plut. Oth. 17.4 and Tac. Hist. 2.49.3-4, with Mouchová 1966:260-261. Van Hooff 1990:18-19 understands the soldiers' reaction as a symbol of their loyalty; on this, see also Plass 1995:107-108, 240-241, n. 17. 
points out, 'Fear in the face of death ... [was the mark] of a bad emperor' ${ }^{36}$ Such a death was therefore something to ridicule, not mourn. We are not meant to pity Nero. Tacitus' account of Nero's death is sadly unavailable to us, for that part of the Annales has not survived. So, it is difficult to tell whether Suetonius' lengthy version of events was influenced by the same underlying source as Tacitus, even if this seems likely enough, with the consular Cluvius Rufus, though in Spain at the time, being the main suspect. ${ }^{37}$ Instead, we merely have epitomes of Cassius Dio, which largely follow Suetonius' version of events, as Bradley (1978:273) observes. ${ }^{38}$ It is difficult to make much of this abbreviated account, yet it is obvious that the accounts of Dio and Suetonius closely resonate with each other.

For Otho, it has been suggested that Suetonius might have softened his treatment of Otho in some way so as to exonerate his father's loyalty to the dead emperor, who came to the purple steeped in Galba's blood. ${ }^{39}$ Yet the exact manner in which he portrays Otho's suicide, down to the very words used, has never really been afforded much attention. In the epitome of Dio, we find no extended account of the last night of Otho's life. There is no tale of two daggers being tested. We are merely told, from excerpts of Zonaras for the most part, that, when calm had been

36 He notes that Nero and Domitian were both tormented by their fear of death, and the dreams that presaged their ends, while Vespasian and Augustus - being 'good' emperors - did not. Are we meant, then, to include Otho in the latter group, at least on this point of detail? On Nero's shameful death, see also Arand 2002:73-77, 112-127, 223-235, 297.

37 On this, see Champlin 2003:49.

38 To summarize, abandoned by everyone, Nero thought of killing all the senators, burning down Rome, and making for Alexandria (Cass. Dio 63.27.2) - a city recalling Marcus Antonius, who had also been declared an enemy (Suet. Aug. 17.2). It is even supposed that Nero intended to live there using his 'talent' as a lyre player to avail him. But, declared an enemy, he rides off, in shabby attire and incognito, to Phaon's house, accompanied by Epaphroditus and Sporus (Cass. Dio 63.27.3). He was recognized and saluted by someone, and so hid himself until daylight. He now considered his fate, and repented his deeds (Cass. Dio 63.28.4). As nobody seemed to be searching for him, he entered a cave, ate some bread and water, but not of the quality to which he had become accustomed (Cass. Dio. 63.28.5). Some horsemen were dispatched to seize him, but even as they approached, Nero's companions refused to kill him. He then attempted to kill himself (no mention of the specific weapon), but only after having lamented 'Zeus,

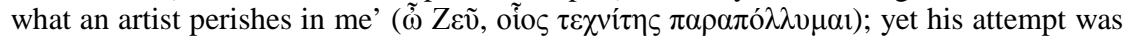
not entirely successful, for Epaphroditus had to end his agony (Cass. Dio 63.29.2).

Although almost exclusively condemnatory towards Nero, Suetonius is often thought to have been quite lenient with Otho, mainly because his father Laetus had once served under him (Oth. 10.1), with Suetonius supposedly wanting to explain why his father would have wanted to support a man generally referred to afterwards as an effeminate tyrant or unwanted usurper. On this, see Hooper 1979:395; Baldwin 1983:184; cf. Morgan 2006:91, 136. 
restored in the camp, Otho stabbed himself with a dagger or small sword ( $\xi_{1} \varphi$ í $\delta i o v:$ Cass. Dio 64.15.1). There is no night's rest, no dagger under the pillow, no left breast. As Shotter (1993:157) puts it, Dio "has none of the "serenity" of Otho's preparation, and represents the suicide as an "act of violence". Tacitus (Hist. 2.49.2) does describe the draught of cold water (gelida aqua), the two daggers being tested, and that Otho placed one of them beneath his head (tum adlatis pugionibus duobus, cum utrumque pertemptasset, alterum capiti subdidit). But he differs from Suetonius by saying that he 'passed a quiet night, and indeed, as is affirmed, he even slept somewhat' (noctem quietam, utque adfirmatur, non insomnem egit: luce prima in ferrum pectore incubuit: Hist. 2.49.2). ${ }^{40}$ Suetonius gives a picture of even greater tranquility. In contrasting the various accounts, Shotter (1993:156) highlights the 'matter-of-fact' nature of Suetonius' version, whereas the Tacitean version captures "the notion of "struggle" on the part of the chief participants'. ${ }^{41}$

By way of contrast, Plutarch (Oth. 17.1) describes the daggers as two full-

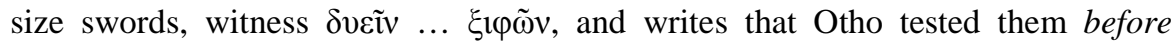
distributing money. He laid one of them aside and put the other under his arm. As with Suetonius, Otho is said to have slept so soundly that he was heard to snore but, just before dawn, he spoke to a freedman about some matters of state; he then advised the freedman to go, lest the soldiers accuse him of assisting the emperor's death (Oth. 17.2). That done, he held out the sword upright with both hands beneath him and fell upon it (Oth. 17.3). Given the general similarities of all these accounts, it is possible to argue that comparison of the deaths of Nero and Otho was already there in the principal source used by all three writers, and possibly even in their supplementary accounts. ${ }^{42}$ Still, it is Suetonius who approximates the two suicides most carefully, to the extent of using the phrase inter moras (Ner. 49.2; Oth. 11.1) to link the two exitus accounts. ${ }^{43} \mathrm{He}$ also presents them in a

40 Shotter 1993:154 claims that, even though Tacitus could not approve of Otho's killing of Galba, he nevertheless 'in no way doubted the sincerity and nobility of Otho's suicide’; see also Tac. Hist. 2.50.1.

${ }^{41}$ Shotter 1993:156 adds that, in Plutarch's account, 'far from being lavishly uncritical, the donations took account of the nature and quality of service each recipient had rendered'.

42 Warmington 1977:114 suggests that there is a principle underlying source to both suicide accounts, together with that of Tacitus, a view supported by Mouchová 1968:57 ('wahrscheinlicher'). He adds that, while Suetonius concentrates almost exclusively on Otho's actions, Dio tends to concentrate on 'rhetorical devices of a more commonplace character to try to make more dramatic what was already dramatic enough'. Mouchová 1966:260-261 also noted similarities between the suicide narratives of Suetonius and Tacitus. On source issues, see also Baldwin 1983:541-546; Murison 1992:126.

43 See Mooney 1930:301. This is also commented on by Mouchová 1968:57: at Oth. 11.1, the phrase is used when Otho postpones his death so as to quell a disturbance among 
contrasting way so as to highlight the frenzied nature of Nero's decease, and the imperial calmness of Otho's. We are almost certainly meant to gain a greater appreciation of Otho's sacrifice by reflecting on the selfish cowardice of Nero. Unlike our other sources, he also provides Otho's last formal announcement: adiciamus ... vitae et hanc noctem (Oth. 11.1). ${ }^{44}$ Again, the contrast with Nero is marked.

In sum, Suetonius is demonstrably ready throughout his Caesares to suppress details recorded by others, or put into greater relief matters mentioned merely in passing elsewhere, all so as to ensure that the work coheres with his overall literary objectives, particularly regarding the presentation of his subjects as 'good', 'bad', or indifferent. ${ }^{45}$ Hence, regardless of Otho's supposedly disgraceful actions as a privatus, we are left to wonder whether his noble death, so different to that of Nero, despite their supposedly similar characters, and even ostensibly similar effeminate appearance, was meant to atone for his less seemly conduct in life. ${ }^{46}$ It seems to have been Suetonius' underlying intention to show that both emperors eventually showed their true (and so markedly different) characters in death. Furthermore, it is well recognized that Suetonius generally tends to arrange his material so that the final impression left is that intended by the author. ${ }^{47}$ This is clearly manifested in his treatment of Otho, which even suggests, at the very end of the Vita, that Otho might have killed Galba, not so much to seek power himself, but to restore liberty to Rome (Oth. 12.2). Here, death is the crucible in which the

his soldiers, while, at Ner. 49.2 , it is employed when Nero hesitates to kill himself, and when a letter arrives announcing his denunciation as a public enemy. Mouchová 1968:56-57 also cites Ner. 49.4 (irrumpenti centurioni) and Oth. 11.2 (irrumpentibusque) as a further example of approximation.

44 On this, see Baldwin 1983:542. Baldwin supposes, not implausibly, that these words are meant to stress the 'supposed superiority of his version's sources', such as his father Laetus.

45 For example, consider the absence of the eunuch Earinus, well known as the beloved of Domitian (who even appears in verse from his own reign), from Suetonius' account of the emperor; on this, see Charles \& Anagnostou-Laoutides 2010:184-185; Jones 1996:143; cf. Vout 2007:15-16; or his lack of reference to the influence wielded by Vespasian's mistress Caenis (recorded at Cass. Dio 66.14.3) in the Vespasianus; on this, see Charles and Anagnostou-Laoutides 2012:537-538.

46 But cf. Plut. Oth. 18.2: 'For though he lived no more decently than Nero, he died more

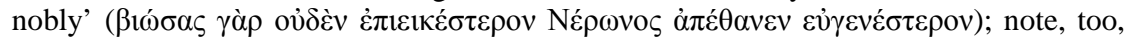
Plut. Oth. 15.6: 'Believe me when I insist that I can die more honourably than I can

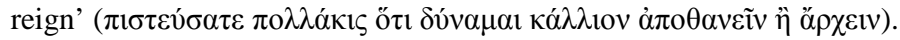

47 Refer to Baldwin 1983:488-490, who deals with Suetonius' penchant for abrupt endings to his Vitae, often with a 'colourful and / or pregnant note'. For analysis of the manipulation of negative characterization in the Vitae, see Cizek 1961:355-356; Bradley 1991:3702-3704; Wardle 1994:87-88; Newbold 1997:passim. 
subject's true character emerges. The effeminate dandy, the architect of plots and the slayer of Galba has morphed into a rather more sympathetic figure. Contrary to Edwards' view that Otho was the only emperor whose true character changed during the course of his life, another interpretation is that his death reveals the character that he would have regularly shown if he had lived longer, and if circumstances had been kinder. ${ }^{48}$ While Nero's death is laughable, being that of a bad actor acting badly in his own horrendously staged play, that of Otho is presented in a much more admirable context, indeed one which might well be emulated by a true Roman statesman - or even an emperor.

\section{BIBLIOGRAPHY}

Arand, T 2002. Das schmähliche Ende: Der Tod des schlechten Kaisers und seine literarischen Gestaltung in der römische Historiographie. Prismata. Beiträge zur Altertumswissenschaft 13. Frankfurt: Peter Lang.

Charles, M B, forthcoming. Nero and Sporus again. Latomus.

Charles, M B \& Anagnostou-Laoutides, E 2010. The sexual hypocrisy of Domitian: Suet. Dom. 8.3. AC 79:173-187.

Charles, M B \& Anagnostou-Laoutides, E 2012. Vespasian, Caenis and Suetonius. In Deroux, C (ed.), Studies in Latin literature and Roman history XVI, 530547, Collection Latomus 338. Brussels: Éditions Latomus.

Baldwin, B 1983. Suetonius. Amsterdam: Hakkert.

Bartsch, S 1994. Actors in the audience: Theatricality and doublespeak from Nero to Hadrian. Cambridge, Mass. \& London: Harvard University Press.

Bardon, H 1956. La littérature latine inconnue. Tome II, l'époque imperial. Paris: Klincksieck.

Bradley, K R 1978. Suetonius' Life of Nero, Collection Latomus 157. Brussels: Éditions Latomus.

Bradley, K R 1991. The imperial ideal in Suetonius' Caesares. ANRW 2.33.5, 3701-3732.

48 Edwards 2007:xvi-xviii comments on the widespread view in antiquity that a person's character was fixed from birth and that Suetonius follows this view with one exception, that of Otho, who despite his vices in early life, died 'probably the noblest death of all the twelve Caesars' (xvi). As Murison 1992:122 states, 'We need not ... be as surprised by Otho's noble end', more so given that his 'banishment' to Lusitania under Nero seems to have sobered him up and inspired a sense of duty; see Suet. Oth. 3.2, with Plut. Galb. 20.1 and Tac. Ann. 13.46.3, where there is even an inkling that Otho's path to statesmanship had begun there (which contrasts markedly with the view of Otho's rise to power as presented in the earlier Historiae, i.e., at 1.22.1, where Otho is lured to depose Galba so as to treat himself to the decadence of a Neronian-style court). On this episode, see Little and Ehrhardt 1994:71. 
Champlin, E 2003. Nero. Cambridge, Mass. \& London: Harvard University Press. Cizek, E 1961. Sur la composition des Vitae Caesarum de Suétone. StudClas 3:355-360.

Connors, C 1994. Famous last words: Authorship and death in the Satyricon and in Neronian Rome. In Elsner, J \& Masters, J (eds), Reflections of Nero: Culture, history, and representation, 225-235. Chapel Hill \& London: University of North Carolina Press.

Edwards, C 2007. Death in ancient Rome. New Haven \& London: Yale University Press.

Erasmo, M 2004. Roman tragedy: Theatre to theatricality. Austin: University of Texas Press.

Erasmo, M 2008. Reading death in ancient Rome. Columbus: Ohio State University Press.

Griffin, M 2000. Nero: The end of a dynasty, repr. of 1984 edn. London: Routledge.

Hill, T 2004. Ambitiosa mors. Suicide and self in Roman thought and literature. New York \& London: Routledge.

Hooper, F 1979. Roman realities. Detroit: Wayne State University Press.

Ipok, R S 1995. Caesarum mortes in Vitis Caesarum: Death scenes of the JulioClaudian rulers in Suetonius' De Vita Caesarum. Chapel Hill: University of North Carolina at Chapel Hill.

Jones, B W 1996. Suetonius: Domitian. Bristol: Bristol Classical Press.

Kaster, R A 2005. Emotion, restraint, and community in ancient Rome. Oxford \& New York: Oxford University Press.

Little, D \& Ehrhardt C 1994. Plutarch. Lives of Galba \& Otho. London: Bristol Classical Press.

Lopes Brandão, J L (Trans.) 2010. Plutarco. Vidas de Galba e Otão. Coimbra:

Centro de Estudos Clássicos e Humanísticos da Universidade de Coimbra.

Lounsbury, R C 1987. The arts of Suetonius: An introduction. New York: P Lang.

Malissard, A 1990. Tacite et le théâtre ou la mort en scène. In Blänsdorf, J (ed.),

Theater und Gesellschaft im Imperium Romanum, 213-222. Tübingen:

Francke.

Mooney, G W 1930. C. Suetoni Tranquilli De Vita Caesarum. Libri VII-VIII. Dublin: Dublin University Press.

Morgan, G 2006. 69 AD: The year of four emperors. Oxford: Oxford University Press.

Mouchová, B 1966. Ausgewählte Parallelen aus der Lebensbeschreibung Kaiser Othos bei Tacitus und Suetons. Listy Filologické 82:267-271.

Mouchová, B 1968. Studie zu Kaiserbiographien Suetons. Prague: Universita Karlova. 
Murison, C 1992. Suetonius: Galba, Otho, Vitellius. London: Bristol Classical Press.

Newbold, R F 1997. Hostility and goodwill in Suetonius and the HA. AncSoc 28:149-174.

O'Gorman, E 2000. Irony and misreading in the Annals of Tacitus. Cambridge: Cambridge University Press.

Plass, P 1995. The game of death in ancient Rome: Arena sport and political suicide. Madison: University of Wisconsin Press.

Rolfe, J C 1997. Suetonius. Vol. 2. LCL, rev. edn. Cambridge, Mass. \& London: Harvard University Press.

Sansone, D 1993. Nero's last hours. ICS 18:179-189.

Shotter, D 1993. Suetonius: The lives of Galba, Otho, and Vitellius. Warminster: Aris \& Phillips.

Shotter, D 2005. Nero, repr. of 1997 edn. London \& New York: Routledge.

Shotter, D 2008. Nero Augustus Caesar: Emperor of Rome. Harlow: Pearson.

Syme, R 1958. Tacitus. Vol 1. Oxford: Oxford University Press.

Syme, R 1971. Emperors and biography: Studies in the Historia Augusta. Oxford: Oxford University Press.

Thomas, J-F 2006. Pudor et Verecundia: deux formes de la conscience morale? Euphrosyne 34:355-368.

Van Hooff, A J L 1990. From autothanasia to suicide: Self-killing in Classical Antiquity. London \& New York: Routledge.

Van Hooff, A J L 2004. The imperial art of dying. In de Blois, L, Erdkamp, P, Hekster, O, de Klijn, G \& Mols, S (eds), The representation and perception of Roman imperial power: Proceedings of the third workshop of the international network Impact of Empire, 99-116. Amsterdam: J C Gieben.

Venini, P 1977. Vite di Galba, Otone, Vitellio. Turin: Paravia.

Vout, C 2007. Power and eroticism in imperial Rome. Cambridge: Cambridge University Press.

Wallace-Hadrill, A 1995. Suetonius, 2nd edn. London: Bristol Classical Press.

Wardle, D 1994. Suetonius' Life of Caligula: A commentary, Collection Latomus 225. Brussels: Éditions Latomus.

Wardle, D 2007. A perfect send-off: Suetonius and the dying art of Augustus (Suetonius, Aug. 99). Mnemosyne 60:443-463.

Warmington, B H 1977. Suetonius. Nero. Bristol: Bristol Classical Press.

Woods, D 2009a. Curing Nero: A cold drink in context. Classics Ireland 16:40-48.

Woods, D 2009b. Nero and Sporus. Latomus 68:73-82. 